\title{
Record of a wild specimen of Redline torpedo fish, Puntius denisonii (Actinopterygii: Cyprinidae) with vertebral deformity
}

Sajan Sajeevan, Thoranam Varkey Anna-Mercy \& Malika Vadakkedath

Department of Fisheries Resources Management, Kerala University of Fisheries and Ocean Studies (KUFOS), Panangad-682506, Kerala, India.

\section{Resumen}

Correspondence

S. Sajeevan

E-mail: sajanpolayil@gmail.com

Received: 14 November 2013

Accepted: 27 February 2014

Published on-line: 5 March 2014
Registro de un ejemplar silvestre de barbo de línea roja, Puntius denisonii (Actinopterygii: Cyprinidae), con deformidad vertebral

Se registró una deformidad vertebral en un ejemplar silvestre de Puntius denisonii de los Ghats occidentales, India. El estudio radiológico y morfológico comparativo de un pez normal y el deforme revelaron una malformación vertebral en la zona caudal de la aleta dorsal. Se discuten las posibles causas de la deformidad vertebral.

Palabras clave: Malformación, Imagen de rayos X, Ghats occidentales, India.

\begin{abstract}
Vertebral deformity was recorded in a wild specimen of Puntius denisonii from Western Ghats, India. Radiological and morphological study of a normal and deformed fish revealed vertebral malformation in the caudal to the dorsal fin. The possible etiologies of vertebral deformity are discussed.
\end{abstract}

Key words: Malformation, X-ray image, Western Ghats, India.

\section{Introduction}

Morphological anomalies are not infrequent in fish, having been recorded in both freshwater and marine fish species. Deformities in fishes are known to be caused as a result of environmental pollutants, scarcity of nutrients, sudden changes in temperature, water current, mutation, inbreeding, parasitic infestation, and attack from predators (Hickey 1973, Amitabh \& Ahmed 2010, Tave et al. 2011). Puntius denisonii (Day, 1865) an ornamental fish popularly known as redline torpedo fish or Miss Kerala is endemic to the rivers flowing through the Western Ghats hotspots of India (Mercy et al. 2013). Due to over exploitation from wild for global ornamental fish trade, this species has been listed as Endangered (Sekharan \& Ra- machandran 2006). This was reported for the first time, a case of deformity in wild population of $P$. denisonii from Western Ghats of India.

\section{Materials and Methods}

Deformed specimen of $P$. denisonii (Total Length $=57 \mathrm{~mm}$, Standard Length $=44 \mathrm{~mm}$, Total Weight $=19.5 \mathrm{mg}$ ) was caught by drag net from Vallithode region of River Valapattanam, $\left(12^{\circ} 1^{\prime}\right.$ 49.44" N, 75 42' 55.44" E), in August 2013. Morphological abnormality was photographed with a digital camera (Nikon Coolpix L22) and deformity was further examined by digital X-ray system (Fujifilm FCR Capsula XL II Reader). For the comparison with deformed specimen, a normal fish (Fig. 1B) of same catch (Total Length $=60$ 
$\mathrm{mm}$, Standard Length $=46 \mathrm{~mm}$ ) was also collected. Deformed specimen stored at the museum of department of fishery biology, College of Fisheries, Kerala.

\section{Results and Discussion}

Compared to the normal fish (Fig. 1B), the deformed specimen of $P$. denisonii possessed vertebral abnormality in the post-dorsal fin region by the examination of morphological length variation (Fig. 1A; Table 1) and radiological observation (Fig. 2A). Similar types of vertebral deformity have been reported in Esox lucius L., 1758 (Orska 1962), Cirrhinus mrigala (Hamilton, 1822) and Hypothalmichthys molitrix (Valenciennes, 1844)

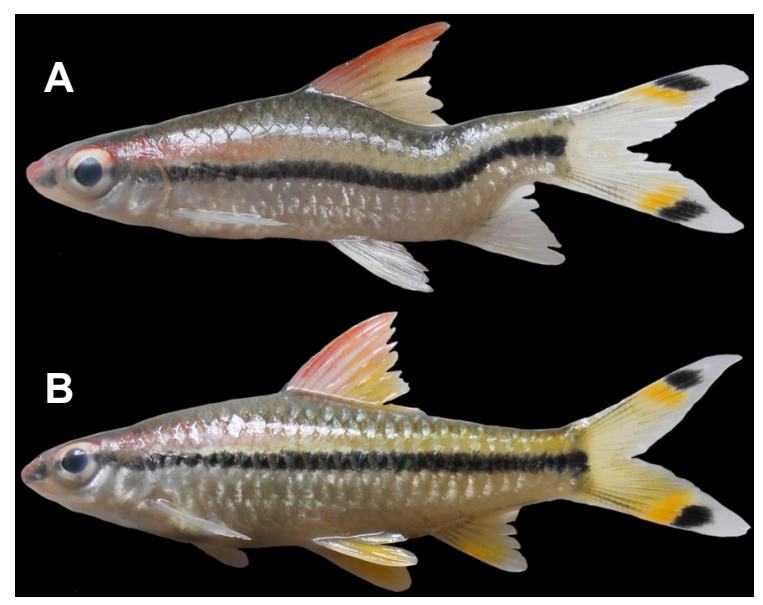

Figura 1. Ejemplares deforme (A) y normal (B) de Puntius denisonii.

Figure 1. Deformed (A) and normal (B) specimens of Puntius denisonii

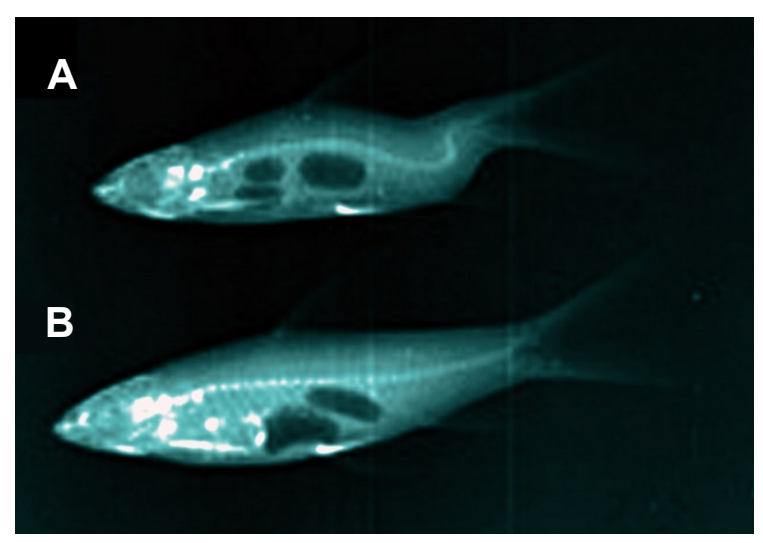

Figura 2. Imagen de rayos $\mathrm{X}$ de ejemplares deforme (A) y normal (B) de Puntius denisonii.

Figure 2. Deformed (A) and normal (B) specimens of Puntius denisonii
(Raj et al. 2004) and Poecilia wingei Poeser, Kempkes \& Isbrücker, 2005 (Arbuatti et al. 2013). The deformed vertebrae in $P$. denisonii were not radiologically differentiated due to the smaller size of the specimen (Standard length $=44 \mathrm{~mm}$ ).

In several fish species the vertebral malformation was found to be associated with the absence of a functional swim-bladder (Andrades et al. 1996). But in deformed P. denisonii had double chambered functional swim-bladder (Fig. 2A), similar to the normal specimen (Fig. 2B). Vertebral deformities in fishes are more common in smaller fishes as compared to larger one which may be due to high mortality of deformed fish at early life stage (Hore and Ahmad 2010). Arbuatti et al. (2013) reported vertebral deformity associated with inbreeding depression in Po. wingei; but no genetic study was analysed to find whether the deformity due to heritable or non-heritable. Vitamin $\mathrm{C}$ deficiency in the diet was also found responsible for the vertebral deformity in Cyprinus carpio L., 1758 (Al-Harbi 2001). In present study, out of 155 normal specimens from the same habitat only one has been found to be deformed, hence the nutrient deficiency theory does not appear to be plausible.

Pesticide exposure has been reported to cause vertebral deformities in Oryzias latipes (Tem-

\begin{tabular}{|c|c|c|c|c|c|}
\hline Variable & NF & AF & $\begin{array}{c}N F \\
\left(\% L_{S}\right)\end{array}$ & $\begin{array}{c}\mathrm{AF} \\
\left(\% L_{S}\right)\end{array}$ & $\begin{array}{c}\% \text { of } \\
\text { variation }\end{array}$ \\
\hline Standard length $\left(L_{S}\right)$ & 4.6 & 4.4 & & & \\
\hline Fork length $\left(L_{F}\right)$ & 5.1 & 4.9 & 110.9 & 111.4 & 0.5 \\
\hline Head depth $\left(D_{H}\right)$ & 0.7 & 0.7 & 15.2 & 15.9 & 0.7 \\
\hline Total length $\left(\mathrm{L}_{T}\right)$ & 6.0 & 5.7 & 130.4 & 129.5 & 0.9 \\
\hline $\begin{array}{l}\text { Body depth at dorsal } \\
\text { fin }\left(D_{B D F}\right)\end{array}$ & 1.2 & 1.1 & 26.1 & 25.0 & 1.1 \\
\hline Head length $\left(L_{H}\right)$ & 1.2 & 1.2 & 26.1 & 27.3 & 1.2 \\
\hline $\begin{array}{l}\text { Body depth at anal } \\
\text { fin }\left(D_{B A F}\right)\end{array}$ & 0.9 & 0.8 & 19.6 & 18.2 & 1.4 \\
\hline $\begin{array}{l}\text { Caudal peduncle } \\
\text { depth }\left(D_{C P}\right)\end{array}$ & 0.6 & 0.5 & 13.0 & 11.4 & 1.7 \\
\hline $\begin{array}{l}\text { Pre anal fin length } \\
\left(L_{\text {PrAF }}\right)\end{array}$ & 3.4 & 3.4 & 73.9 & 77.3 & 3.4 \\
\hline $\begin{array}{l}\text { Post anal fin length } \\
\left(L_{P O A F}\right)\end{array}$ & 2.6 & 2.3 & 56.5 & 52.3 & 4.2 \\
\hline $\begin{array}{l}\text { Pre dorsal fin length } \\
\left(L_{P r D F}\right)\end{array}$ & 2.1 & 2.2 & 45.7 & 50.0 & 4.3 \\
\hline $\begin{array}{l}\text { Caudal peduncle } \\
\text { length }\left(L_{C P}\right)\end{array}$ & 0.8 & 0.5 & 17.4 & 11.4 & 6.0 \\
\hline
\end{tabular}

Tabla 1. Medidas corporales de los ejemplares normal y anormal de Puntius denisonii. NF: Normal; DF: Deforme.

Table 1. Morphological measurements of normal and abnormal specimens of Puntius denisonii. NF: Normal specimen; DF: Deformed specimen 
minck \& Schlegel, 1846) (Hiraoka \& Okuda 1983), Channa punctatus (Bloch, 1793) (Sen et al. 1991), and Ci. mrigala (Dutta et al. 2011). Recent study by Kerala State Council for Science, Technology and Environment (KSCSTE) (The Hindu 2013) documents that River Valapattanam has been polluted by the extensive usage of pesticides in adjacent land for agriculture and also by dynamite or chemical fishing methods. Such high levels of pollutants in the River Valapattanam could affect the embryonic and early larval stages of fishes. Malformations in fishes are used as indicators of water pollution, because of their incidence in polluted areas (Sun et al. 2009). Environmental stress related deformities were recorded in $\mathrm{Ci}$. mrigala and Hypothalmichthys molitrix (Valenciennes, 1844) from Bhavani River in Tamil Nadu (Raj et al. 2004). We found that dynamite fishing is one of the major threats over the freshwater fishes of River Valapattanam. However, the dynamite fishing has been banned vide by The Travancore Cochin Fisheries Act of 1950, there is very little or no enforcement from the concerned authorities and the practice continues in the rivers of Kerala (Baby et al. 2011).

From the above discussion, it is clear that the fish deformities are very complex and are caused by multiple factors. Even though the exact cause of deformity was not being determined; combination of pollutants, pesticides, or genetic factors can be supposed to be involved in $P$. denisonii. Other factors might be equally responsible for developmental anomalies. Detailed investigation is required to determine the cause of deformity and genetically its impacts over the standing stock. However, the present record is nevertheless significant owing to the occurrence of deformity in wild population of $P$. denisonii (Kerala- India).

\section{Acknowledgements}

Scholarship by Government of Kerala for the doctoral research (2010-13) is greatly acknowledged. Our thanks are also due to the X-ray department (Anonymous Hospital), Ernakulum, Kerala for their special assistance.

\section{References}

Al-Harbi AH. 2001. Skeletal deformities in cultured common carp Cyprinus carpio L. Asian Fisheries Science 14: 247-254.
Amitabh H, Ahmed MF. 2010. A wild specimen of Indian Carp, Cirrhinus mrigala (Ham) 1822 with multiple Vertebral Deformities. World Journal of Zoology 5(8): 167-177.

Andrades J, Becerra J \& Fernandez-Llebrez P. 1996. Skeletal deformities in larval, juvenile and adult stages of cultured sea bream (Sparus aurata L.). Aquaculture 141: 1-11.

Arbuatti A, Salda LD \& Romanucci M. 2013. Spinal deformities in a wild line of Poecilia wingei bred in captivity: report of cases and review of the literature.Asian Pacific Journal of Tropical Biomedicine 3(3): 186-190.

Baby F, Tharian J, Philip S, Ali A \& Raghavan R. 2011. Checklist of the fishes of the Achankovil forests, Kerala, India with notes on the range extension of an endemic cyprinid Puntius chalakkudiensis. Journal of Threatened Taxa 3(7): 1936-1941.

Dutta SPS, Slathia D, Chander G \& Kumar H. 2011. Anomalies in Cirrhinus mrigala, a commercially important fresh water food fish, from Gurdaspur district of Punjab. The Bioscan 6(3): 405-411.

Hickey CR. 1973. Common abnormalities in fishes, their causes and effects. Transactions of the Northeast Fish and Wildlife Conference 1972: 71-83.

Hiraoka Y, Okuda H. 1983. Characteristics of vertebral abnormalities in medaka as a water pollution indicator. Environmental research 34: 262-267.

Hore A, Ahmad MF.2010.A wild specimen of Indian Carp, Cirrhinus mrigala (Hamilton 1822) with multiple vertebral deformities. World journal of Zoology 5(3): 167-171.

The Hindu. 2013. Study reveals pollution of four river basins. The Hindu, $7^{\text {Th }}$ June. Available at http:// www.thehindu.com/todays-paper/tp-national/study-re veals-pollution-of-four-river-basins/article4790410.ec e (Accessed on June 2013).

Mercy TVA, Malika V \& Sajan S. 2013. Reproductive biology of Puntius denisonii (Day 1865)- an endemic ornamental cyprinid of the Western Ghats of India.Indian Journal of Fisheries 60(2): 73-78.

Orska J. 1962. Anomalies in the vertebral columns of the Pike Esox lucius. Acta Biological Cracovtenym Series for Zoology 5: 327-345.

Raj AJA, Seetharaman S \& Haniffa MA. 2004. Skeletal deformities in few freshwater fishes from Bhavani River, Tamil Nadu. Zoos print Journal 19(9): 16281629.

Sekharan M, Ramachandran A. 2006. Market preferred indigenous ornamental fishes of Kerala. OFI Journal 52: 20-21.

Sen G, Behera MK \& Patel PN. 1991. Toxicity of zinc to the fish Channa punctatus (Bloch) with behavioural, morphological and skeletal abnormalities. Environmental Ecology 9: 1023-1027.

Sun PL, Hawkins WE, Overstreet RM \& Brown PNJ. 2009. Morphological deformities as biomarkers in fish from contaminated rivers in Taiwan. International Journal of Environmental Research in Public Health 6: 2307-2331.

Tave D, Jo JY \& Kim DS. 2011. Gross Abnormalities in Tilapia. Fisheries and Aquatic Science 14(2): 148160. 